\title{
Arsenic mobilization in shallow aquifer of Bengal Delta Plain: role of microbial community and pathogenic bacteria
}

\author{
P. Ghosh \& D. Chatterjee \\ Department of Chemistry, University of Kalyani, Kalyani, West Bengal, India
}

\begin{abstract}
In West Bengal, India, arsenic, iron and microbial contamination has been reported from shallow aquifers $(<50 \mathrm{~m})$ of the Bengal Delta Plain (BDP). Six groundwater affected side at Chakdaha Block of Nadia District in West Bengal was selected to study groundwater quality parameter notably arsenic and microbial contamination. The study revealed that arsenic contamination is the highest in site $\mathrm{B}$ (up to $0.171 \mathrm{mg} \mathrm{L} \mathrm{L}^{-1}$ ), whereas site $\mathrm{E}$ has been identified as the lowest $\left(0.089 \mathrm{mg} \mathrm{L}^{-1}\right)$ and rest are in between. Similarly microbial contamination has been the highest in site $\mathrm{D}$ and the lowest in site A. Further, high concentrations of arsenic along with microbial contamination have also been found in several sites A, C, D and F. The field scale study indicated simultaneously occurrences of arsenic and microbial contamination, suggesting role of microbial pollution in arsenic mobilization.
\end{abstract}

\section{INTRODUCTION}

Arsenic (As) is one of the numerous toxicants that is naturally/anthropogenically introduced into the aquatic ecosystem impairing the water quality and also impairing life of different aquatic species (Biswas et al., 2012). Microorganism has developed several mechanisms that can transform arsenic by extracellular precipitation, intracellular accumulation or oxidation and reduction reaction (Oremland \& Stolz, 2003). Interestingly, different arsenic resistant bacteria belonging to enteric group has been isolated from the arsenic prone zone. Some common bacteria Pseudomonas, Geobacter grbicium, Clostridium are isolated from BDP (Islam et al., 2004; Chatterjee et al., 2010, van Geen et al., 2011).

\section{METHODS/EXPERIMENTAL}

\subsection{Study area}

Ground water samples were collected from six sides (Site- A, B, C, D, E, F) of Bengal Delta Plain (BDP) in Chakdaha Block, West Bengal, India.

\subsection{Sample analysis}

Total arsenic (As) concentration in the samples was measured by hydride generation atomic absorption spectrophotometer (HG.AAS VARIAN-240, detection limit $<1 \mu \mathrm{g} \mathrm{L}^{-1}$ ). Membrane filtration method was used to determine total coliforms and Thermo tolerant fecal coliforms present in the ground water
Table 1. Variation in the abundance of arsenic and microbial population in groundwater at the study sites.

\begin{tabular}{llll}
\hline Site & {$[$ As] $\%$} & {$[\mathrm{MO}] \%$} & [As \& MO] $\%$ \\
\hline A & 81.66 & 38.75 & 32.87 \\
B & 26.97 & 34.21 & 15.13 \\
C & 60.37 & 36.22 & 27.16 \\
D & 23.82 & 54.04 & 24.68 \\
E & 31.42 & 32.14 & 18.21 \\
F & 44.55 & 68.31 & 34.65 \\
\hline
\end{tabular}

samples. This microbial population was enumerated on Chromocult Agar and differentiated by standard methods as per US-EPA.

\section{RESULTS AND DISCUSSION}

\subsection{Results}

Considerable variation in concentration of arsenic in groundwater between the collection sites as well as between different depths were observed. Based on the arsenic content, the total study samples could be set high arsenic content $\left(0.103-0.171 \mathrm{mg} \mathrm{L}^{-1}\right)$.

\subsection{Discussion}

We have observed that in all the six sites under study, high amount arsenic and microbial contamination is present (Fig. 1). Similarly Figure 1c shows that at A, C, D \& F sites both arsenic and microbes are present. 


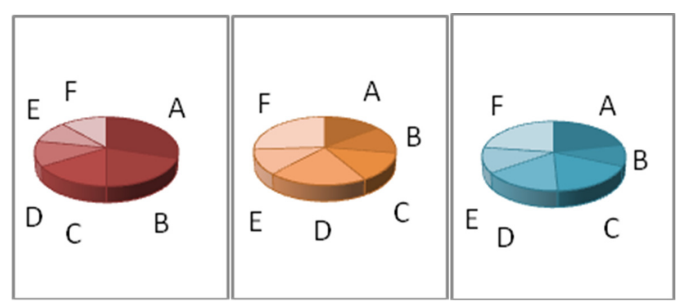

(a)

(b)

(c)

Figure 1. Distribution of a) total arsenic, b) total microbial population, and c) arsenic \& microbial population in groundwaters at the study sites A to F.

Another proposed hypothesis is due to the release of arsenic sorbed to aquifer minerals by competitive exchange with microbial phosphate ions that migrates into aquifers due to application of fertilizer to surface soil. In all the situations, the released iron (II) is also oxidized to iron (III) in the presence of oxygen.

\section{CONCLUSIONS}

Our study indicates that As and microbial activities, specifically fecal coliforms which gains entry into water by fecal contamination. However, too much availability of As into water affects microbial activity and hence shows negative corelation with As-Fe coimmobilization.

\section{ACKNOWLEDGEMENTS}

The authors are thankful to the DST-PURSE funding given to the Department of Chemistry, University of Kalyani.

\section{REFERENCES}

Biswas, A., Nath, B., Bhattacharya, P., Halder, D.\& Kundu, A.K. 2012. Hydrogeochemical contrast between brown and grey sand aquifers in shallow depth of Bengal Basin: Consequences for Sustainable drinking water supply, Sci.Total Environ. 431: 402-412.

Chatterjee, D., Halder, D., Majumder, S., Biswas, A. \& Nath, B. 2010. Assessment of arsenic exposure from groundwater and rice in Bengal Delta region, West Bengal, India. Water Res. 44: 5803-5812.

Islam, F.S., Gault, A.G., Boothman, C., Polya, D.A., Charnock, J.M., Chatterjee, D. \& Lloyd, J.R. 2004. Role of metal-reducing bacteria in arsenic release from Bengal delta sediments. Nature 430(6995): 68-71.

Oremland, R.S. \& Stolz, J.F. 2003. The ecology of arsenic. Science 300(5621): 939-944.

van Geen, A., Ahmed, K.M., Akita, Y., Alam, M.J., Culligan, P.J., Emch, M., Escamilla, V., Feighery, J., Ferguson, A.S., Knappett, P., Layton, A.C., Mailloux, B.J., Mcakay, L.D., Mey, J.L., Serre, M.L., Streatfield, P.K., Wu, J. \& Yunus, M. 2011. Fecal contamination of shallow tubewells in Bangladesh inversely related to arsenic. Environ. Sci. Technol. 45(4): 1199-1205. 